\title{
PENGALAMAN MENGGUNAKAN ALAT KONTRASEPSI MANTAP (VASEKTOMI) DI KECAMATAN WANASABA KABUPATEN LOMBOK TIMUR
}

\author{
Tri Utami \\ STIKes Husada Mandiri Poso \\ trutmi27@gmail.com
}

\begin{abstract}
Abstrak
Latar Belakang: Metode kontrasepsi wanita sebesar 93,66\%, sedangkan metode kontrasepsi pria hanya sebesar 6,34\%. Hal tersebut menunjukkan bahwa partisipasi pria dalam menggunakan alat kontrasepsi masih sangat rendah.Rendahnya kesertaan pria dalam program yaitu lebih kurang 5 persen.Partisipasi pria dalam program keluarga berencana sangat penting karena pria merupakan partner dalam reproduksi, sehingga suami dan istri perlu berbagi tanggung jawab dan peran secara seimbang. Tujuan: mengeksplorasi informasi yang mendalam mengenai pengalaman menggunakan alat kontrasepsi mantap (vasektomi) di Kecamatan Wanasaba Kabupaten Lombok Timur. Metode Penelitian: Penelitian ini menggunakan metode kualitatif dengan pendekatan studi fenomenologi. Partisipan dalam penelitian ini terdiri atas 4 partisipan.Pemilihan partisipan ditetapkan secara langsung (purposive). Teknik pengumpulan data dalam penelitian ini dilakukan dengan cara wawancara mendalam. Hasil Penelitian:penelitian ini mengidentifikasi ada 2 tema , yaitu: 1) motivasi menggunakan vasektomi meliputi perasaan setelah pemasangan vasektomi, dorongan kader/PLKB, dorongan dari diri sendiri, dan kelebihan yang dirasakan, 2) Dampak menggunakan vasektomi meliputi perubahan fisik, efek psikologi, gairah seksual, dan keluhan setelah pemasangan. Hasil penelitian ini dapat menjadi gambaran kepada petugas kesehatan dalam upaya promosi kesehatan tentang pentingnya keikutsertaan pria dalam menggunakan alat kontrasepsi mantap, tingkatkan sosialisasi program dengan menggunakan media sosialisasi elektronik seperti televisi dan radio.
\end{abstract}

Kata kunci: Pengalaman menggunakan vasektomi, motivasi, dampak, alat kontrasepsi mantap, vasektomi

\section{Pendahuluan}

SDGs (Sustainable develpoment goals) merupakan sebuah acuan dalam kerangka pembangunan di perundingan negara - negara di dunia. Pada September 2015 lalu di New York, Amerika Serikat, secara resmi telah mengesahkan agenda berkelanjutan SDGs sebagai kesepakatan pembangunan global dimulai tahun 2016 2030. Salah satu tujuan pembangunan berkelanjutan adalah seperangkat target yang berhubungan dengan pengembangan internasional di masa mendatang yang termaksud ialah mengenai kesetaraan gender (SDGs, 2016).

Program keluarga berencana dapat mendukung upaya pengendalian pertumbuhan penduduk. Program keluarga berencana yang berkualitas dapat mewujudkan keluarga yang sejahtera, sehat, mandiri, maju, mempunyai jumlah anak yang ideal, bertanggung jawab, memiliki wawasan ke masa depan, harmonis dan bertaqwa kepada Tuhan Yang Maha Esa. Untuk meningkatkan kualitas program KB, paradigma baru yang dibangun oleh BKKBN adalah penekanan upaya 
JURNAL ILMU KESEHATAN BHAKTI HUSADA:

HeAlth SCIENCES Journal, Vol. 09 No. 02, DeSEMBER 2018 DOI: https://doi.org/10.34305/jikbh.v9i2.69

menghormati hak-hak reproduksi dalam meningkatkan kualitas kehidupan keluarga (BKKBN, 2011).

Menurut Peraturan Pemerintah Republik Indonesia Nomor 87 Tahun 2014 Tentang Perkembangan Kependudukan Dan Pembangunan Keluarga, Keluarga Berencana, Dan Sistem Informasi Keluarga, yang dimaksud dengan program keluarga berencana $(\mathrm{KB})$ merupakan upaya mengatur kelahiran anak, jarak dan usia ideal melahirkan, mengatur kehamilan, melalui promosi, dan merupakan salah satu strategi untuk mengurangi kematian ibu khususnya ibu dengan kondisi 4T; terlalu muda melahirkan (dibawah usia 20 tahun), terlalu sering melahirkan, terlalu dekat jarak melahirkan, dan terlalu tua melahirkan (di atas usia 35 tahun) (Kemenkes RI, 2014).

Dalam Rencana Pembangunan

Jangka Menengah Nasional (RPJMN) penggunaan alat kontrasepsi ada 2 metode yang digunakan yaitu Metode Kontrasepsi Jangka Panjang (MKJP) dan Non Metode Kontrasesi Jangka Panjang (Non MKJP). Non MKJP suntik 49,67\%, pil sebesar $25,14 \%$, dan kondom 5,68 \%. Sementara itu MKJP meliputi IUD 7,15, MOP (Metode Operasi Pria) 0,21\%, MOW (Metode Operasi Wanita) 1,50\%, dan Implant 10,65 (Kemenkes RI, 2014).

Dilihat dari jenis kelamin, metode kontrasepsi wanita yang digunakan jauh lebih besar dibanding dengan metode kontrasepsi pria. Metode kontrasepsi wanita sebesar 93,66\%, sedangkan metode kontrasepsi pria hanya sebesar $6,34 \%$. Hal tersebut menunjukkan bahwa partisipasi pria dalam menggunakan alat kontrasepsi masih sangat rendah. Rendahnya kesertaan pria dalam program yaitu lebih kurang 5 persen (BKKBN, 2009). Hasil tersebut menunjukkan masih rendahnya keikutsertaan para suami untuk menjadi akseptor kontrasepsi MOP. Dibeberapa daerah pemerintah memberikan hadiah atau imbalan bagi yang ingin menjadi akseptor MOP guna meningkatkan keikutsertaan para suami (BKKBN, 2014).
Ciptaan disebarluaskan di bawah

Lisensi Creative Commons Atribusi-

NonKomersial-BerbagiSerupa 4.0

Internasional.

Berdasarkan data yang diperoleh Dinkes Lombok Timur, pencapaian tertinggi pada tahun 2016 yaitu kecamatan wanasaba dengan 504 akseptor. Hal ini menunjukkan bahwa vasektomi masih memiliki peminat yang cukup tinggi khususnya di Kecamatan Wanasaba. Keberhasilan program vasektomi di Kecamatan Wanasaba didasari oleh kemauan dari masyarakat, khususnya pria yang dalam hal ini menjadi target program. Sehubungan dengan penggunaan metode kontrasepsi vasektomi di Kabupaten Lombok Timur khususnya di Kecamatan Wanasaba ada beberapa faktor yang turut berperan dalam pengambilan suatu keputusan seperti pengetahuan, peran tenaga kesehatan, budaya bahkan mengikuti anjuran yang disampaikan oleh petugas kader KB.

Vasektomi merupakan metode operasi dengan jalan memotong vas deferens sehingga saat ejakulasi tidak terdapat spermatozoa dalam cairan sperma (Manuaba et all, 2009). Suatu model konsep keperawatan mengenai budaya dikembangkan oleh Dr. M. Leininger yang mengemukakan bahwa teori ini menjabarkan konsepkeperawatan yang didasari oleh pemahaman tentang adanya perbedaannilai-nilaikultural yang melekat dalam masyarakat dan beranggapan bahwa sangatlahpenting memperhatikan keanekaragaman budaya dan nilai-nilai dalam penerapanasuhan keperawatan kepada klien. Asuhan keperawatan dalam konteks budaya digambarkan dalam bentuk matahari terbit (sunrise model) menyatakan bahwa proses keperawatan ini digunakan oleh perawat sebagai landasan berfikir dan memberikan solusi terhadap masalah klien (Andrew and Boyle, 1995).

Peran perawat dalam program keluarga berencana adalah sebagai konselor dan edukator. Untuk melaksanakan ini perawat harus memiliki informasi terbaru dan akurat tentang metode kontrasepsi. Dalam pemilihan kontrasepsi perawat memiliki peranan penting dalam memberikan pendidikan tentang teknik 
JURNAL ILMU KESEHATAN BHAKTI HUSADA:

HeALTH SCIENCES JOURNAL, Vol. 09 No. 02, DESEMBER 2018 DOI: https://doi.org/10.34305/jikbh.v9i2.69

kontrasepsi yang sesuai dengan kebutuhan, cara penggunaan yang tepat, dan fokus konselingnya haruslah pada kebutuhan dan kenyamanan pasangan yang akan menggunakan alat kontrasepsi (maryati, 2014).

Hasil penelitian dengan menggunakan desain studi kualitatif yang dilakukan di enam negara yaitu Bangladesh, Sri Langka, Kenya, Meksiko, Rwanda dan Amerika Serikat tentang faktor-faktor kunci yang menyebabkan orang untuk memilih vasektomi dan peran pasangan dalam pengambilan keputusan. Dibeberapa negara mereka memiliki alasan menggunakan vasektomi karena faktor budaya, ekonomi dan ras. Alasan yang utama dari semua negara yang mengunakan vasektomi yaitu karena kepedulian terhadap kesehatan wanita. Namun di Bangladesh dan Sri Lanka peran perempuan dalam mendorong laki-laki untuk menggunakan vasektomi cenderung masih terbatas bila dibandingkan dengan empat negara lainnya dalam pengambilan keputusan penggunaan vasektomi (Landry \& Ward, 1995, dikutip oleh yudi, 2015).

Namun fenomena pengalaman menggunakan alat kontrasepsi vasektomi di Kecamatan Wanasaba Kabupaten Lombok Timur masih belum diketahui secara pasti.

Mengacu pada hasil penelitian dan data yang menunjukkan tingkat vasektomi yang cukup tinggi di daerah lombok timur dan belum diketahuinya dampak yang terjadi setelah dilakukan vasektomi serta masih kurangnya penelitian yang dipublikasikan terkait dengan pelikaku sesual setelah dilakukan tindakan vasektomi terkait perubahan perilaku seksual. Dengan demikian penelitian ini bertujuan untuk menggali lebih dalam lagi bagaimana pengalaman menggunakan alat kontrasepsi mantap serta perilaku seksual (vasektomi) di Kecamatan Wanasaba Kabupaten Lombok Timur.

\section{Metode Penelitian}

DesainPenelitian ini menggunakan metode kualitatif dengan pendekatan studi fenomenologi. Penelitian kualitatif adalah penelitian yang pada umumnya menjelaskan dan memberikan pemahaman dan interprestasi tentang berbagai perilaku dan pengalaman manusia (individu). Peneliti menggunakan pendekatan fenomenologi secara transenden/deskriptif, karena berfokus pada berbagai pengalaman individu yang bersifat universal, filosofi fenomenologi yang mengeksplorasi secara langsung, menganalisis dan mendiskripsikan fenomena yang diteliti melalui pengungkapan instituisi penelitian secara maksimal terhadap fenomena yang diteliti (Afiyanti,

2014)

\section{Hasil Penelitian}

\section{GambaranKarakteristik Partisipan}

Data karakteristik diperoleh dari hasil wawancara dan disajikan dalam bentuk table dibawah ini

Tabel 4.1

Karakteristik Partisipan 
JURNAL ILMU KESEHATAN BHAKTI HUSADA:

HeAlth SCIENCES Journal, Vol. 09 No. 02, DeSEMBER 2018

DOI: https://doi.org/10.34305/jikbh.v9i2.69
Ciptaan disebarluaskan di bawah

Lisensi Creative Commons Atribusi-

NonKomersial-BerbagiSerupa 4.0

$\begin{array}{llccccccc}\text { No Nama } & \text { Usia } & \begin{array}{c}\text { Pendidikan } \\ \text { terakhir }\end{array} & \begin{array}{c}\text { Status } \\ \text { pernikahan }\end{array} & \text { Agama } & \text { Pekerjaan } & \text { Alamat } & \text { Suku } & \begin{array}{c}\text { Lama } \\ \text { penggunaan }\end{array}\end{array}$

\begin{tabular}{cccccccccc}
\hline 1. & P1 & 50 & SD & Kawin & Islam & Tani & Wanasaba & Sasak & 4 tahun \\
\hline 2. & P2 & 53 & SD & Kawin & Islam & Buruh Tani & Wanasaba & Sasak & 4 tahun \\
\hline 3. & P3 & 51 & SD & Kawin & Islam & Buruh Tani & $\begin{array}{c}\text { Karang } \\
\text { Baru }\end{array}$ & Sasak & 3 tahun \\
\hline 4. & P4 & 49 & SD & Kawin & Islam & Tani & $\begin{array}{c}\text { Karang } \\
\text { Baru }\end{array}$ & Sasak & 5 tahun \\
\hline
\end{tabular}

Berdasarkan tabel 4.1 diatas menunjukkan bahwa partisipan dalam penelitian ini berjumlah 4 partisipan, usia partisipan berkisar dari 49-53 tahun, pendidikan terakhir SD, pekerjaan tani dan buruh tani, suku sasak, lama penggunaan 3 tahun -5 tahun.

\section{Analisis tematik}

Berdasarkan hasil penelitian yang telah dilakukan dengan wawancara mendalam, tema yang didapatkan terdiri dari 2 tema yaitu ; 1) Motivasi menggunakan vasektomi, 2) Dampak yang dirasakansetelah menggunakan alat kontrasepsi mantap (vasektomi).

\section{a. Tema 1 : Motivasi Menggunakan Vasektomi}

Persepsi tentang motivasi menggunkan alat kontrasepsi mantap (vasektomi) diawali dengan memberikan pertanyaan. "Bisakah bapak ceritakan, bagaimana pengalaman bapak menggunakan alat kontrasepsi mantap (vasektomi)"

Hasil wawancara menunjukkan bahwa semua partisipan memiliki motivasi menggunakan alat kontrasepsi mantap (vasektomi) meliputi perasaan setelah pemasangan vasektomi, keluhan setelah pemasangan, dorongan kader PLKB/orang lain, dorongan dari diri sendiri, dan kelebihan yang dirasakan.Semua partisipan dalam penelitian ini menceritakan gambaran tentang pengalaman menggunakan alat kontrasepsi mantap (vasektomi).

Pengalaman mereka tentang bagaimana perasaan setelah pemasangan vasektomitersebut, meliputi: tambah sehat, takut akan efek samping, dan merasa senang menggunakan vasektomi. Salah satu partisipan menuturkan perasaan setelah pemasangan vasektomitersebut, meliputi: tambah sehat, tambah semangat bekerja, dan merasa senang mengunakan vasektomi, berikut penuturannya:

"Endekwah sakit jak, sehat terus...arak rasa takut efek samping sebelum masang... seneng beruta ngadu, seneng ita. Laguknaa laaaaah kenang tiang bauk te sedik, arak ndek narak ongkatna kena, munarak ongkatna ndekna taa masang laek....(P1)"

Pengalaman mereka tentang bagaimana keluhan setelah pemasangan penggunaan alat kontrasepsi mantap (vasektomi) meliputi: sakit sedikit saat pemasangan, alat vital tersa lemas, sifatnya permanen dan merasa lemas saat pemasangan. Salah satu partisipan menuturkan keluhan setelah pemasangan vasektomi tersebut, meliputi: sakit sedikit saat pemasangan, alat vital terasa lemas, sifatnya permanen dan merasa lemas saat pemasangan, berikut penuturannya:

"Pas naa masang doang sakit ne sekedik, sakit semendak. ....Lemas sekedik alat vital ta beruk jerak taa masang, endek na sue berubah normal malik...(P2)"

Pengalaman mereka tentang dorongan dari pemerintah/orang lain. Semua partisipan dalam penelitian ini menceritakan bagaimana dorongan dari pemerintah/orang lain untuk menggunakan alat kontrasepsi mantap (vasektomi). Salah satu partisipan menuturkan adanya dorongan dari pemerintah/orang lain dalam memilih menggunakan alat kontrasepsi mantap (vasektomi) tersebut, meliputi: disarankan oleh kader PLKB, dorongan dari 
JURNAL ILMU KESEHATAN BHAKTI HUSADA:

HeAlth SCIENCES Journal, Vol. 09 No. 02, DeSEMBER 2018 DOI: https://doi.org/10.34305/jikbh.v9i2.69

teman, dan dorongan dari istri. Berikut pernyataan dari parisipan.

"Ibu kader...diminta dengan istri dulu,dikasih sama istri... (P1)"

"Mau taa cerita pin batur...(P2)"

"Istilahna soo pemerintah dengar taa, mintak izin sama istri, sama kadus apa kee, terus diizinin, langsung....(P4)"

Sedangkan salah satu partisipan menuturkan adanya dorongan dari diri sendiri dalam memilih menggunakan alat kontrasepsi mantap (vasektomi) diantaranya karena adanya kesadaran diri sendiri, karna kondisi ekonomi, dan banyak anak. Berikut pernyataan dari parisipan:

"Ekonominya tidak ada, anak banyak susah kita.... (P1)"

"Yaa...mengurangi anak dan kondisi ekonomi....(P2)"

Hasil wawancara menunjukkan bahwa semua partisipan menjelasakan bagaimana kelebihan menggunakan alat kontrasepsi mantap (vasektomi) yang meliputi kelebihan.

Semua partisipan dalam penelitian ini menceritakan bagaimana kelebihan menggunakan alat kontrasepsi mantap (vasektomi). Salah satu partisipan menuturkan kelebihan menggunakan alat kontrasepsi mantap (vasektomi) tersebut, meliputi: operasi cepat, tidak ada kompilkaisi, efektifitas mengunakan vasektomi, merasa aman, dan biaya pemasangan gratis. Berikut pernyataan dari parisipan:

"Cepat...nggeh (ngaguk)...aman ...biaya gratis.....(P1)",

"Ndek na sue, sekitar 15 menit...Narak efek samping, baguss...ia wah idapna bagus, menurut tiang efektif ....Aman...ndek, gratis... (P2)"”.

b. Tema 2 : Dampak yang dirasakan setelah menggunakan alat kontrasepsi mantap (vasektomi)

Hasil wawancara menunjukkan bahwa semua partisipan menjelasakan bagaimana dampak yang dirasakan setelah menggunakan alat kontrasepsi mantap (vasektomi) yang meliputi perubahan fisik, efek psikologi, kemampuan berhubungan dan gairah seksual.Semua partisipan dalam penelitian ini menceritakan secara kooperatif tentang bagaimana dampak yang dirasakan setelah menggunakan alat kontrasepsi mantap (vasektomi).

Salah satu partisipan menuturkan perubahan fisik yang dirasakan setelah menggunakan alat kontrasepsi mantap (vasektomi) tersebut, meliputi : bengkek pada daerah operasi dan lemas pada alat vital. Berikut pernyataan dari parisipan:

"Aloe perubahan fisik taa, terutama bekas operasi ia bengkak bejelo-jelo....lemas iaa kelaminta....(P1)",

"Iaa kurang waah, sak julu jerak operasi arak idapna bengkak zakarta...Iaa lemas doing sekedik sekenokta (alat vital). (P2)"

Sedangkan salah satu partisipan menuturkan efek psikologi yang dirasakan setelah menggunakan alat kontrasepsi mantap (vasektomi) diantaranya: merasa cemas sebelum pemasangan, tidak merasa takut saat pemasangan, dan tambah semangat bekerja. Berikut pernyataan dari parisipan:

"Baa...takut-takut beranian (ketawa).... begawean tetap, begawean jak semangat...(P1)"

"Biasa(ketawa)...ee...biasa wah semangat taa begawean ....(P2)”

Salah satu partisipan menuturkan lama berhubungan intim setelah menggunakan alat kontrasepsi mantap (vasektomi) tersebut, meliputi : waktu dalam 1 kali berhubungan intim dan kemampuan berhubungan intim dalam 1 hari. Berikut pernyataan dari parisipan:

"Lima sampe enam kali sejelo sekelam (ketawa)Mun setelah taa masang sekenek entah sekali sejelo.... (P1)”

" Seminggu sekali soalna taa bekerja jaok.....(P2)"

Sedangkan empat partisipan menuturkan gairah berhubungan intim setelah menggunakan alat kontrasepsi mantap (vasektomi) seperti gairah seksual semakin meningkat. Berikut pernyataan dari parisipan: 
JURNAL ILMU KESEHATAN BHAKTI HUSADA:

HeAlth SCIENCES Journal, Vol. 09 No. 02, DeSEMBER 2018 DOI: https://doi.org/10.34305/jikbh.v9i2.69

"Manjulu jak na lebih bergairah,... (P1)" "Sebelum naa lebih gairah awal-awal masang....kurang yaa wah nengka umurtaa wah lanjut...(P2)"

\section{Pembahasan}

Hasil penelitian tentang pengalaman menggunakan alat kontrasepsi mantap (vasektomi), dari empat partisipan didapatkan 2 tema yaitu :1) Motivasi menggunakan vasektomi, dan 2) Dampak yang dirasakan menggunakan vasektomi. Masing-masing tema akan diuraikan berdasarkan tujuan khusus penelitian.

\section{Gambaran pengalaman partisipan menggunakan alat kontrasepsi mantap (vasektomi)}

Dalam mengidentifikasi pengalaman partisipan menggunakan alat kontrasepsi mantap (vasektomi) diperoleh satu tema yaitu motivasi menggunakan vasektomi.

\section{Tema 1. Motivasi menggunakan vasektomi}

Merasa senang merupakan salah satu perasaan pria setelah dilakukan vasektomi. Hal tersebut terjadi karena sebelum melakukan vasektomi, pria telah mendapat penjelasan dari petugas pos $\mathrm{KB}$ setempat mengenai prosedur, kelebihan, keterbatasan, dan lain sebagainya. Setelah melalui proses diskusi dengan keluarga, dan mendapatkan ijin dari keluarga, pria langsung bersedia untuk dilakukan vasektomi.

Dalam pengambilan keputusan pasangan dilibatkan dan dilakukan secara bersama-sama antara partisipan dengan pasangan. Berdasarkan hasil penelitian yang dilakukan oleh Desmalia dan kawankawan di Kelurahan tembilahan kota menyatakan bahwa ada hubungan peran istri dengan partisipasi pria sebagai peserta KB (Desmalita, Nursal, \& Suryati, 2008).

Sedangkan empat partisipan menuturkan adanya dorongan dari diri sendiri dalam memilih menggunakan alat kontrasepsi mantap (vasektomi) diantaranya karena adanya kesadaran diri sendiri, karna kondisi ekonomi, dan banyak anak.
Menurut BKKBN (2009), jumlah anak yang lahir hidup dikelompokkan menjadi dua, yaitu: 0-2 orang paritas rendah dan 3 orang atau lebih paritas tinggi. Keputusan untuk menambah jumlah anak diserahkan kepada suami istri dan disesuaikan dengan standar BKKBN yaitu jumlah anak kurang atau sama dengan dua.

Adapun alasan pria melakukan vasektomi adalah karena jarak kelahiran anak terlalu dekat. Dalam pasal 18 UU no.10 tahun 1992 yang menyatakan bahwa setiap pasangan suami istri dapat menentukan pilihannya dalam merencanakan dan mengatur jumlah anak dan jarak kelahiran anak berdasarkan pada kesadaran dan tanggung jawab terhadap generasi sekarang maupun yang akan datang.

Selain memperoleh pelayanan yang gratis partisipan yang menggunakan vasektomi juga diberikan rewards oleh pemerintah. Vasektomi merupakan solusi pemerintah dalam upaya pengendalian kelahiran dan menjadi solusi yang diterima oleh partisipan karena dianggap membawa manfaat. Bahkan pemerintah memberikan bantuan kepada kelompok vasektomi untuk meningkatkan kesejahteraan ekonomi para akseptor vasektomi.

Ada kelebihan yang menonjol dari metode KB MOP atau Vasektomi ini adalah : lebih efektif, aman, sederhana, waktu operasi cepat hanya memerlukan waktu 510 menit, menggunakan anestesi lokal, biaya rendah, secara budaya sangat dianjurkan untuk negara yang penduduk wanitanya malu ditangani tenaga medis pria (Hartanto, 2004).

\section{Teridentifikasi perubahan psikologi dan perilaku seksual setelah menggunakan alat kontrasepsi mantap}

Dalam mengidentifikasi perubahan psikologi dan perilaku seksual yang dirasakan setelah menggunakan alat kontrasepsi mantap (vasektomi) diperoleh satu tema yaitu dampak yang dirasakan menggunakan vasektomi. 


\section{Tema 2 : Dampak yang dirasakan menggunakan vasektomi}

Hasil penelitian ini menunjukkan bahwa sebagian besar partisipan mengungkapkan perubahan fisik yang dirasakan setelah menggunakan alat kontrasepsi mantap (vasektomi) tersebut, meliputi: bengkak pada daerah operasi dan lemas pada alat vital.

Perubahan pada organ reproduksi setelah operasi semua partisipan mengatakan ada perubahan.Hasil penelitian ini sesuai dengan perubahan patofisiologi pascaoperasi vasektomi, perubahan terjadi pada semua area saluran genital pada bagian proksimal.

McMahon et al. (1992) menemukan dalam penelitiannya chronic testicular pain dilaporkan pada $33 \%$ pria setelah vasektomi, dengan $5 \%$ datang ke petugas kesehatan untuk mencari bantuan. Choe dan Kirkemo (1996) mengidentifikasi chronic scrotal pain sebanyak $18,7 \%$ pada pasien setelah vasektomi, di mana berdampak atau mempengaruhi kualitas hidupnya sebanyak $2,2 \%$.

Hampir semua responden dalam penelitian ini menyatakan kurang begitu memperhatikan perubahan anatomi pada organ reproduksi secara detail hal ini disebabkan sebagian responden telah lupa karena vasektomi lebih dari 5 tahun. Keluhan alat vital lemas, nyeri punggung, perut, dan badan tidak enak dan tidak nyaman pada organ reproduksi sampai sekarang (empat bulan) dikeluhkan oleh satu partisipan. Ahmed et al., (1997) salah satu masalah yang dirasakan setelah vasektomi adalah chronic testicular pain, di mana nyeri dirasakan intermittend atau constant pada bagian unilateral atau bilateral selama sama dengan atau lebih tiga bulan setelah operasi vasektomi.

Chronic testicular atau scrotal pain adalah salah satu komplikasi yang yang dapat terjadi setelah vasektomi dengan insiden yang tidak diketahui (Manikandan et al, 2003).Nyeri atau ketidaknyamanan setelah vasectomy merupakan salah satu alasan bagi pasien untuk mendatangi petugas kesehatan dan menjadi alasan untuk menolak vasektomi. Temuan ini menjadi penting diperhatikan oleh petugas kesehatan untuk selalu memberikan informasi yang sejelas-jelasnya kepada pasien mengenai efek samping dan kemungkinan yang terjadi setelah vasektomi agar pasien siap (McMahon,et al., 1992).

Dari hasil penelitian dua orang mengatakan tidak takut saat mengunakan vasektomi dikarenakan keinginan yang kuat dalam diri, semangat untuk menggunakan vasektomi, dimana penelitian ini berlawanan dari penjelasan (Bucklew, 1980 dalam Trismiati, 2004) dimana kecemasan tingkat psikologis yakni kecemasan yang berwujud sebagai gejala-gejala kejiwaan seperti tegang, takut, bingung, khawatir, sukar berkonsentrasi, dan sebagainya saat pemasangan vasektomi.

Namun, perasaan takut itu hanya sementara, setelah mereka mencoba untuk melakukan hubungan seksual setelah vasektomi, mereka merasakan perasaan yang sama seperti sebelum vasektomi, menurut mereka tidak ada perubahan rasa dalam berhubungan seksual setelah dilakukan vasektomi.

Perasaan awal takut saat akan berhubungan seksual dirasakan pria setelah dilakukan vasektomi. Takut akan adanya efek samping vasektomi ketika berhubungan seksual. Hal tersebut merupakan kecemasan normal yakni pada saat individu masih menyadari konflikkonflik dalam diri yang menyebabkan cemas (Jersild, 1963 dalam Trismiati, 2004).

Penelitian ini sejalan dengan penelitian yang dilakukan oleh Yusro dalam Noorastuti dan Abdinah (2011), responden yang bersedia divasektomi mengakui bahwa frekuensi hubungan seksual dengan istri meningkat bahkan bisa mencapai dua kali ejakulasi semalam. Peningkatan frekuensi hubungan seksual ini terjadi karena secara psikologis suami istri tidak terbebani dan adanya rangsangan-rangsangan dari dalam yang 
JURNAL ILMU KESEHATAN BHAKTI HUSADA:

HeAlth SCIENCES Journal, Vol. 09 No. 02, DeSEMBER 2018 DOI: https://doi.org/10.34305/jikbh.v9i2.69

muncul ketika sperma terhenti di sekitar testis.

Selama proses menunggu tubuh menghancurkan sperma tersebut, ada rangsangan yang menusuk saraf di sekitar alat kelamin sehingga keinginan mencapai kenikmatan seksual pun bertambah. Partisipan yang menyatakan kemampuan seksualnya lebih baik diartikan sebagai kemampuan melakukan hubungan seksual mampu bertahan lebih lama dari pada sebelum operasi, melakukan hubungan lebih sering.

Perasaan semakin bergairah dan tahan lama saat berhubungan seksual, perasaan awal takut akan efek samping vasektomi, perasaan yang sama seperti sebelum dilakukan vasektomi merupakan berbagai hal yang dirasakan pria setelah dilakukan vasektomi. Perasaan semakin bergairah dan tahan lama dirasakan pria saat berhubungan seksual.

Hal tersebut sesuai dengan pengalaman Wahyuni saat berhubungan seksual setelah suaminya dilakukan vasektomi. Wahyuni dalam BKKBN (2012), mengatakan bahwa gairah seks akan semakin tinggi setelah vasektomi, bisa tiga kali dalam satu malam, rata-rata pria yang sudah ikut vasektomi akan semakin bergairah dalam masalah ranjang, sebab tidak ada kekhawatiran akan terjadi kehamilan yang tidak diinginkan.

\section{Kesimpulan}

Mitos yang terjadi dimasyarakat pada umumnya bahwa akseptor setelah menggunakan vasektomi penis tidak dapat berdiri, gairah seks menurun pasca operasi, tidak akan bisa ejakulasi lagi, terasa lemas sedangkan hasil penelitian yang didapatkan oleh peneliti dimana partisipan menjelasakan bahwa pada umumnya mereka kurang memperhatikan perubahan yang terjadi dan menganggap bahwa bila istri tidak komplain berarti tidak ada masalah dan tidak menganggap masalah seksual sebagai masalah yang perlu dibahas, yang penting melakukan hubungan seksual antara suami dan istri adalah menunaikan kewajiban dan kemampuan berhubungan intim 3 sampai 4 kali dalam sehari dan mampu berhubungan antara 1 sampe 2 jam dalam sekali berhubungan setelah mengunakan vasektomi, kemampuan berhubungan intim setelah mengunakan vasektomi lebih meningkat dibandingkan sebelumnya.Dimana vasektomi tidak mempengaruhi kemampuan seorang pria dalam menikmati hubungan seksual.

\section{Saran}

Hasil penelitian ini dapat menjadi gambaran kepada petugas kesehatan dalam upaya promosi kesehatan tentang pentingnya keikutsertaan pria dalam menggunakan alat kontrasepsi. Sebagai penyuluh, metode dalam penyuluhan harus lebih menarik dan interaktif agar informasi yang diberikan dapat tersampaikan dengan lebih baik. Dalam penyuluhan, materi yang disampaikan harus singkat, jelas, dan padat serta alat aga yang digunakan harus legkap dan menarik.

\section{Daftar Pustaka}

Adriaansz, Wiknjosastro dan Waspodo. 2007. Buku Acuan Nasional Pelayanan Kesehatan aternal dan Neonatal. Jakarta : Yayasan Bina Pustaka Sarwono Prawiroharjdo.

Afiyanti, Y dan Rachmawati, N.I. (2014).Metodologi Penelitian Kualitatif Dalam Riset Keperawatan, edisi 1, Rajawali Pers, Jakarta

Andik dan Siti Novianti, (2015. "Faktor Determinan Partisipasi Pria Dalam Vasektomi”. Fakultas Ilmu Kesehatan Universitas Siliwangi : Tasikmalaya.

Anna, Glasier. 2005. Keluarga Berencana dan Kesehatan Reproduksi. Jakarta: EGC.

Ayu, adityawilly (2014).Vasektomi pada pria.https://ayuadityawilly.wordpress. 
JURNAL ILMU KESEHATAN BHAKTI HUSADA:

HeALTH SCIENCES JOURNAL, Vol. 09 No. 02, DESEMBER 2018 DOI: https://doi.org/10.34305/jikbh.v9i2.69

com/2014/01/15/vasektomi pada pria/ayuadityawilly.

Bappenas. Laporan akhir: evaluasi pelayanan keluarga berencana bagi masyarakat miskin (keluarga prasejahtera/KPS dan keluarga sejahtera-1/KS-1, Jakarta: Bappenas. 2010.

Bararah, Vera farah. Untung Rugi vasektomi untuk Pria. Jakarta : detik health. 2010.

Bunce, et.al (2007), Factors Affecting Vasectomy Acceptability in Tanzania.

Christina, et.al (2014), Knowledge and Attitude of Men Abour Vasectomy as a Method of Family Planning among married man woking in Babcock University, Ogun State, Nigeria.

Fresadita, dkk, 2011."Hubungan Pengetahuan Dan Sikap Istri Dengan Pemilihan Kontrasepsi Vasektomi Pada Pasangan Usia Subur”. Universitas diponegoro : semarang.

BKKBN. 2011: Cara-cara Kontrasepsi yang Digunakan Dewasa Ini. Surabaya : Kanwil BKKBN Propinsi Jatim. http://www.bkkbnjatim.go.id/bkkbn-51.

BKKBN.(2011). Buku Panduan Praktis Pelayanan Kontrasepsi. Jakarta: PT Bina Pustaka Sarwono Prawiroharjo. Retrieved from binapustaka@yahoo.com

BKKBN.Sri Wahyuni, 2012 : Beberkan Usahanya Ajak kaum Pria untuk vasektomi. Jawa Timur. http://jatim.bkkbn.go.id/berita.php?p= berita_detail\&id $=657$.

BKKBN. 2012: Minat KB Pria Vasektomi di Propinsi Gorontalo Meningkat .Gorontalo.http://gorontalo.bkkbn.g o.id/ViewArtikel.aspx?ArtikelID=5 0.

BPS NTB.(2012). Badan Pusat Statistik NTB tahun 2012.

Brahmana, BR Ide, (2011), Alat Kontrasepsi Keluarga Berencana Pria di Kalangan Pegawai Negeri Sipil Badan Pemberdayaan
Perempuan dan Keluarga Berencana Kota Medan Sumatra Utara.

Chi, M.T.H., N. de Leeuw, M.H. Chiu, dan C. Lavancher. 1994. Eliciting Self Explanation Improves Understanding. Cognitive Science. 18: 439-477

Creswell, J.W. (2013), Research Design Pendekatan Kualitatif, Kuantitatif dan Mixed: Prosedur-prosedur Metode Campuran, Pustaka Pelajar, Yogyakarta, pp 316-317

Davison, G.C\& Neale J.M. (2006). Psikologi Abnormal. Jakarta: PT. Raja Grafindo Persada.

Departemen Kesehatan Republik Indonesia.( 2013). Laporan Nasional Riset Kesehatan Dasar. Jakarta: Pusat penelitian pengembangan kesehatan.

DEPKES.(2013). Riset Kesehatan Dasar 2013.Diakses dari http://depkes.go.id/download/riskesda s2013/hasil\%20Riskesdas\%202013.P df.

Depkes.(2014), Profil Kesehatan Indonesia 2014. Jakarta.

Dhini. 2010. Faktor-faktor yang mempengaruhi ketidakmauan pria dalam ber-KB (MOP). http://mursyidstai.blogspot.co.id/2010 /07/proposal-dhini.html.

Ditjen.BGKIA, Kesehatan Dalam Kerangka Sustainable Development Goals (Sdgs).

2015.http://www.pusdatin.kemkes.go. $\mathrm{id} /$ resources/download/pusdatin/infod atin).

Fitri, Wantouw, Tendean (2013). Pengaruh Vasektomi terhadap Funsi Seksual Pria: Jurnal e-Biomedik (eBM), Volume 1, Nomor 1, Maret 2013, hlm. 496-502

Freddy Candra Sitepu.Kehidu eksual vs Kontrasepsi Mantap.I on 21 January 2014 under Healthy Sex.http://reps-id.com/kehidupanseksual-vs-kontrasepsi-mantap/.

Glasier, Anna \& Gebbie Alisa (2006), Keluarga berencana \& kesehatan reproduksi, Jakarta : EGC. 
JURNAL ILMU KESEHATAN BHAKTI HUSADA:

HeALTH SCIENCES JOURNAL, Vol. 09 No. 02, DESEMBER 2018 DOI: https://doi.org/10.34305/jikbh.v9i2.69

Hani, (2012).Pengalaman pria dalam menggunakan vasektomi di desa babakan sari kecamatan sukaluyu. Universitas islam Negeri : Jakarta.

Hartanto, Hanafi. 2004, Keluarga Berencana dan Kontrasepsi, Pustaka Sinar Harapan, Jakarta.

Kementrian Kesehatan. Profil Kesehatan Indonesia Tahun 2014.(http://www.depkes.go.id/resour ces/download/pusdatin/profil-

kesehatan-indonesia/profil-kesehatanindonesia-2014.pdf)

Kesehatan Dalam Kerangka Sustainable Development Goals (SDGs). Jakarta: Kemenkes RI; 2015.

Marmi, (2016), Buku ajar pelayanan KB, Yogyakarta : Pustaka belajar.

Manuaba, I.A.C., Manuaba, I.B.G.F. 2009.Keluarga Berencana. Dalam: Manuaba, I.A.C.,Manuaba, I.B.G.F. (eds). Memahami Kesehatan Reproduksi Wanita.Edisi 2. Jakarta: EGC, 235-238.

Manuaba, et al. 2009.Memahami Kesehatan Reproduksi Wanita. Jakarta: EGC

Maureen dan Jennifer; 2007.Textbook of Medical Surgical Nursing.Vol 2.Hal. 1027.

Notoatmodjo, S. 2007. Promosi Kesehatan dan Ilmu Perilaku.Jakarta : Rineka Cipta.

Reeder DM, Frank CL, Turner GG, Meteyer CU, Kurta A, Britzke ER, Vodzak ME, Darling SR, Stihler CW, Hicks AC, Jacob R, Grieneisen LE, Brownlee SA, Muller LK, Blehert DS. 2012. Frequent arousal from hibernation linked to severity of infection and mortality in bats with white-nose syndrome. PLoS One 7:e38920.

RicaAnindyarani, 2015.Faktor-Faktor Yang Mempengaruhi Keberhasilan Program Kb Pria Di Kabupaten Situbondo (Studi Kasus Program Mop (Medis Operatif Pria)/Vasektomi Di
Ciptaan disebarluaskan di bawah

Lisensi Creative Commons Atribusi-

NonKomersial-BerbagiSerupa 4.0 Internasional

Kecamatan Banyuputih).Digital Repository Universitas Jember

Roy, S.C. and Heather, A. A. (1991).The Roy Adaptation Model - the Definitive Statement. USA: Appleton \& Lange.

Saifuddin, Abdul Bari, dkk. 2009. Ilmu Kebidanan, edisi 4, cetakan 2. Jakarta : Yayasan Bina Pustaka Sarwno Prawirohardjo.

Saifuddin, Abdul Bari, dkk. 2009. Buku Acuan Nasional Pelayanan Kesehatan Maternal dan Neonatal. Jakarta : Yayasan Bina Pustaka Sarwno Prawirohardjo

Sastroasmoro Sudigdo (2016), Dasar dasar Metodologi Penelitian Klinis, CV. Sagung seto, Jakarta

Satria, Yurni. Isu Gender dalam Kesehatan Reproduksi.Pusat Pelatihan Gender dan Peningkatan Kualitas Perempuan.Jakarta : BKKBN. 2005.

Smeltzer, Suzanne C \& Bare, Brenda G.2002. Keperawatan “ likal Bedah. Jakarta: EGC

Tomey, Marriner dan Alligood ( 2016$)$ Nursing Theorists and their Work, Philadelphia.

Trismiati.2004. Perbedaan Tingkat Kecemasan Antara Pria dan Wanita Akseptor Kontrasepsi Mantap Di RSUP Dr. Sardjito Yogyakarta. Jurnal Psyche. Vol. 1 No. 1.

Van manen, M. (2007).Researching lived experience: Human science for action sensitive pedagogy. London, $\mathrm{ON}$ : Althouse.

Walgito, W. 2003.Psikologi Sosial (Suatu Pengantar). Yogyakarta: Andri Offset.

Widowati, (2013).Pencapaian Program KB Pria: Vasektomi di Kecamatan Dlingo dan Sewon, Kabupaten Bantul. Yogyakarta : Universitas Gadjah Mada.

Yudi Ardiana, (2015), Penerimaan Kontrasepsi Vasektomi Di Kecamatan Wanasaba Kabupaten Lombok Timur. Denpasar : Universitas udayana. 